\title{
The dark side(s) of the EU Directive on copyright and related rights in the Digital Single Market
}

\section{Federico Ferri ${ }^{1}$ iD}

Accepted: 23 October 2020 / Published online: 16 November 2020

(c) The Author(s) 2020

\begin{abstract}
The article examines some pivotal aspects of Directive (EU) 2019/790, which is the new legislative act adopted by the European Union to adapt copyright to the evolving digital environment. Indeed, this measure is meant to have considerable implications on the European plane and is supposed to influence, at least in part, also the relations between the EU and third States in the field of copyright. The Directive shall be transposed by mid 2021, but the time is ripe for a first assessment and some reflections. The analysis primarily investigates the relationship between Digital Single Market and EU copyright law and focuses on the most controversial issues of a long-awaited piece of legislation that so far has been widely criticized. In particular, the article explores three new key points: mandatory exceptions and limitations to right holders' exclusive rights, press publishers' rights, and platforms' liability.
\end{abstract}

Keywords Copyright · Digital Single Market · Exceptions and limitations · Press publishers $\cdot$ Platforms $\cdot$ Liability

\section{Introduction}

Just a couple of months before last European elections, one of the top goals of the outgoing Juncker Commission finally saw the light. Directive (EU) 2019/790 on copyright and related rights in the Digital Single Market (DSM Directive), symbolising the "copyright revolution" at the European Union level, was adopted by the European Parliament and the Council of the EU on 17 April 2019. It shall be transposed by the Member States before 7 June 2021.

At first sight, this novelty seems to be a fundamental one in view of the fact that the EU reform on copyright received a great deal of media attention. The final stage of the "legislative train" took place after many years of cumbersome procedures involving political institutions, national policy makers and relevant stakeholders.

Federico Ferri

federico.ferri5@unibo.it

1 Department of Legal Studies, University of Bologna, Via Zamboni 27-29, 40100 Bologna, Italy 
The amendments to the old-fashioned legal framework are likely to make a remarkable impact both at national and at supranational level. Copyright law intersects with many other sectors covered by supranational law and this reform is thus expected to produce a domino effect. Furthermore, from the EU perspective the new rules on copyright might as well mark a turning point in the negotiations with third countries whenever aspects concerning intellectual property-especially intellectual property rights - have to be dealt with; that applies not only to agreements specifically concluded to regulate intellectual property, but also to more comprehensive instruments, such as free trade agreements.

Therefore, the aim of the article is to analyse the major challenges resulting from Directive (EU) 2019/790. To do that, Sect. 2 introduces the reference framework, while Sect. 3 explains that reaching an institutional agreement on the text of the Directive was very difficult. Sections 4 and 5 touch upon the main general and controversial aspects of the directive. Section 6 concludes.

\section{The Directive put into context}

\subsection{The "Digital Single Market"}

The background of the DSM Directive is the new digital environment framed by the European Union. Already in the first decade of the years 2000s, the EU moved digitization towards the heart of its political agenda. Basically, after the launch of the "Europe 2020" strategy, containing the flagship initiative "A Digital Agenda for Europe", ${ }^{1}$ the idea was to develop and bring about a Digital Single Market (DSM). According to the European Commission, the transition to a DSM would entail enormous advantages for the European Union as a global competitor and for the Member States when cooperating in the EU framework.

Needless to say, the transition to a DSM at the early stages rested on the proliferation of political and programmatic acts, but yet in the short run it started to depend also on the activity of the EU legislator. New legislative acts are being adopted to amend the existing acquis in numerous sectors or to fill gaps for the first time. In addition, legislative acts passed by the European Parliament and the Council are meant to support the consolidation of this new "archetype" by introducing either obligations or multifaceted forms of financial support.

Nowadays, the expression "Digital Single Market" remains rather ambiguous. To use the words of the Commission, the DSM is "is one in which the free movement of goods, persons, services and capital is ensured and where individuals and businesses can seamlessly access and exercise online activities under conditions of fair competition, and a high level of consumer and personal data protection, irrespective of their nationality or place of residence". In particular, it is not clear whether in the view of the Commission the DSM should be an autonomous market, a "new

\footnotetext{
${ }^{1}$ Communication from the Commission "Europe 2020 A strategy for smart, sustainable and inclusive growth” COM(2010) 2020 final, 3 March 2010, especially p. 14.
} 
generation" policy of the EU or a cross-cutting sector of the whole internal market. Similar concerns regard the specific contents of the DSM, as the multiple strategies adopted to pursue such goal are not always consistent under this point of view. Despite all that, it seems obvious that the DSM is aimed at eliminating those national barriers that keep affecting the flow of activities carried out online or which are closely related to the latest technological developments; to list but a few, cloud computing, internet of the things, artificial intelligence.

\subsection{Copyright in the DSM}

In this emerging scenario, copyright certainly plays a major role. Indeed, the importance of copyright and its regulation under EU law for the purposes of the DSM was evident since the elaboration of the above mentioned European Digital Agenda. Right after the "Europe 2020" strategy was published the Commission seized the opportunity to underscore that simplifying copyright clearance, management and cross-border licensing was a key action to lower the barriers that were separating all various and diverging "online markets" within the EU, thereby inhibiting the potential of the internet. ${ }^{2}$ More precisely, the absence of a EU-driven framework for the efficient management of copyright across the EU was "significantly complicating the process of making knowledge and cultural goods available online". The Commission opined that in order to achieve a digital market it was necessary, among the other things, to unleash the potential of online distribution by combining the need to enhance the availability of creative content with the right holders' interest to obtain adequate remuneration and protection for their works. Therefore, the roadmap drew down by the Commission included the submission by 2011 of a proposal for a framework Directive on the management of copyrights designed to open up access to online content by improving the governance transparency and electronic management of copyright. ${ }^{3}$

Despite the issues surrounding the reforming process envisioned by the Commission, the priority of amending long-lasting EU copyright pieces of legislation ${ }^{4}$ was never abandoned; among those acts is Directive 2001/29/EC ${ }^{5}$-also known as "Infosoc Directive"-, the forerunner of the Directive addressed by this work. ${ }^{6}$ The

\footnotetext{
${ }^{2}$ Communication from the Commission to the European Parliament, the Council, the European Economic and Social Committee and the Committee of the Regions "A Digital Agenda for Europe", $\operatorname{COM}(2010) 245$ final, 19 May 2010, pp. 7-9. For further considerations see Ricolfi 2013.

${ }^{3}$ Communication from the Commission to the European Parliament, the Council, the European Economic and Social Committee and the Committee of the Regions "Towards a Single Market Act For a highly competitive social market economy. 50 proposals for improving our work, business and exchanges with one another", $\operatorname{COM(2010)} 608$ final, 27 October 2010, p. 8.

${ }^{4}$ For comprehensive analysis of the EU acquis on copyright see, for instance, Rosenmeier et al. 2019, Ramalho 2016, Caso and Giovannella 2015, Stamatoudi and Torremans 2014.

${ }^{5}$ Directive 2001/29/EC of the European Parliament and of the Council of 22 May 2001 on the harmonisation of certain aspects of copyright and related rights in the information society, OJEC L 167/10.

${ }^{6}$ Communication from the Commission to the European Parliament, the Council, the European Economic and Social Committee and the Committee of the Regions "Single Market Act II. Together for New Growth", COM(2012) 573 final, 3 October 2012, p. 15.
} 
Infosoc Directive has been a milestone in the field of copyright, a domain in which the EU was not conferred a high degree of competences by the Member States. It was passed under the "pressure" of the 2000 Lisbon Agenda to adapt legislation on copyright and related rights to technological developments and to transpose in the then Community law the main obligations arising from the international treaties adopted in the framework of the World Intellectual Property Organisation (WIPO) in $1996 .^{7}$ The Infosoc Directive introduced minimum harmonization patterns on some aspects of copyright and related rights in the context of the digital information society. It sets forth exclusive rights for authors and lists many discretionary exceptions that Member Stares are free to endorse in national law.

However, after about a decade, Directive 2001/29/EC was no longer fit to carry out its mission in an efficient way, since it failed to consider many new or upcoming aspects brought by the evolution of the internet-based environment. The way anyone interacts with items protected by copyright has radically changed; downloading files, reading and sharing news online, remixing content, accessing streaming TV are activities that can efficiently flourish provided that updated rules are available. In sum, taking steps forward towards a DSM entails the modernization of the legal framework depicted through the Infosoc Directive. ${ }^{8}$

As a result, the Infosoc Directive cannot properly tackle acts of illegal upload of copyrighted materials on platforms sharing those contents to the wider public. Software piracy and non-authorized streaming have evolved to the point that rights and business models related to creators of multimedia works in recent years have been exposed to considerable risks. Actually, the only defensive instruments for right holders lie in the "E-commerce Directive" (Directive 2000/31/EC").

In the context of the digitization of the EU, copyright is to be recognized a pivotal and multifaceted function. ${ }^{10}$ That can be easily inferred also by the first official DSM strategy for Europe, where the Commission identified the stream "Better access to digital content-A modern, more European copyright framework" as one of the primary means to ensure better online access for consumers and businesses across Europe. $^{11}$

\footnotetext{
7 The Copyright Treaty and the Performers and Phonograms Treaty, which were signed at the WIPO Diplomatic Conference of Geneva on 20 December 1996.

${ }^{8}$ See in particular European Council, Conclusions of 28 and 29 June 2012, EUCO 76/12, p. 10. The strategy proposed by the European Council in that occasion-the so called "Compact for Growth and Jobs" also highlights that the establishment of a well-functioning DSM by 2015 requires facilitating licensing, while ensuring a high level of protection of intellectual property rights and taking into account cultural diversity. This point at least shows that the Commission and Member States had some common ideas about the general approach to follow in the field of copyright.

9 Directive 2000/31/EC of the European Parliament and of the Council of 8 June 2000 on certain legal aspects of information society services, in particular electronic commerce, in the Internal Market ('Directive on electronic commerce'), OJEC L 178.

10 Not only in the EU, but also at international level. See Gervais 2017.

11 Communication from the Commission to the European Parliament, the Council, the European Economic and Social Committee and the Committee of the Regions "A Digital Single Market Strategy for Europe", COM(2015) 192 final, in particular pp. 6-8. In this regard, it is also interesting to note the emphasis at times placed by the Commission on copyright in previous strategies elaborated to frame and promote the DSM. See in particular Communication from the Commission "On content in the Digital Single Market", $\operatorname{COM(2012)~789,~final,~} 18$ December 2012, p. 2. See also Communication from the
} 


\section{Brief considerations on the preparatory works}

Regardless of the copyright-related priorities set in the strategies briefly outlined above, the European regime on copyright construed at the end of ' 90 s survived almost integrally even in the aftermath of the launch of the core strategy on the DSM.

As one can imagine, especially in recent times the Court of Justice of the European Union (ECJ) had to withstand the weight of interpreting EU copyright law in a way to adapt it to peculiar situations which had not previously been foreseen by the EU legislator. The result of this complex work has been a vast set of judgments pointing to scattered reference criteria. Predictably, the case-by-case approach of the Court has turned out to be simply a palliative, given that the it could not be expected to reduce the impact of so many different national measures in a multi-speed context. ${ }^{12}$ That goes also for cases characterized by conflicts between copyright and diverging interests in the landscape of fundamental rights. ${ }^{13}$

Despite this intricate legal latticework, it is a matter of fact that no official proposals to amend the Infosoc Directive were tabled until 2016. ${ }^{14}$ Even though reforming the Infosoc Directive was considered an urgent step to take, the "arena" was divided into various interest groups. In general terms, the clash was between those who sought a high degree of protection of the materials circulating through the interned and those who demanded to use this virtual space as a means to ensure maximum extension to the free movement of online contents. However, multiple actors entered this legal and political battlefield; tech platforms_-led by Google-and tech trade associations, collecting societies (organizations created to manage copyright payments), creative industries and publishers, stakeholders representing web users. Reportedly, preparatory works of the 2019 Directive were targeted by unprecedented lobbying campaigns addressed to the European Parliament. ${ }^{15}$

\footnotetext{
Footnote 11 (continued)

Commission to the European Parliament, the Council, the European Economic and Social Committee and the Committee of the Regions "Towards a modern, more European copyright framework", 9 December 2015, COM(2015) 626 final.

12 For detailed information see Rosati 2019.

13 For example, ECJ, C-275/06, Pomusicae, 29 January 2008, ECLI:EU:C:2008:54; C-324/09, Scarlet Extended, 24 November 2011, ECLI:EU:C:2011:771; C-360/10, SABAM, 16 February 2012, ECLI:EU:C:2012:85; C-461/10, Bonnier Audio, 19 April 2012, ECLI:EU:C:2012:219; C-283/11, Sky Österreich, 22 January 2013, ECLI:EU:C:2013:28; C-65/12, Leidseplein Beheer, 6 February 2014, ECLI:EU:C:2014:49; C-314/12, UPC Telekabel Wien, 27 March 2014, E CLI:EU:C:2014:192; C-201/13, Deckmyn, 3 September 2014, ECLI:EU:C:2014:2132; C-170/13, C-484/14, Mc Fadden, 15 September 2016, ECLI:EU:C:2016:689; C-161/17, Renckhoff, 7 August 2018, ECLI:EU:C:2018:634; C-149/17, Bastei Lübbe, 18 October 2018, ECLI:EU:C:2018:841; C-469/17, Funke Medien, 29 July 2019, ECLI:EU:C:2019:623; C-476/17, Pelham, 29 July 2019, ECLI:EU:C:2019:624; C-516/17, Spiegel online, 29 July 2019, ECLI:EU:C:2019:625. See also Husovec 2016, Griffiths and McDonagh 2013.

14 European Commission, Proposal for a Directive of the European Parliament and of the Council on copyright in the Digital Single Market, COM(2016) 593 final, 2016/0280 (COD).

15 See also https://www.europarl.europa.eu/news/en/press-room/20190111IPR23225/questions-andanswers-on-issues-about-the-digital-copyright-directive.
} 
Tension between interest communities so far apart ${ }^{16}$ reflected in the activities of the EU institutions as well. Before reaching the final agreement on the text to adopt, prolonged debates were conducted either within each of the institutions involved in the decision-making process or under a multilateral institutional perspective. A symptomatic episode was the provisional rejection by the European Parliament's plenary of the decision to start negotiations with the Council, in July $2018^{17}$; and it should also be underlined that during this negotiation process the two rapporteurs that have followed over time pursued different objectives. ${ }^{18}$

Against this background, the outcome of this lengthy debate could be nothing than a compromise solution. The DSM Directive was first approved by the European Parliament in plenary by 348 votes in favor, 274 against and 36 abstentions ${ }^{19}$; then it was passed by the Council, with 6 Member States voting against. Many points contained in the Commission's draft proposal and in the first positions adopted by the European Parliament and the Council are not (fully) replicated in the text of Directive (EU) 2019/790.

\section{General aspects}

Directive (EU) $2019 / 790^{20}$ constitutes a step forward the harmonization in the realm of copyright under EU law. Harmonization mainly concerns the rights of the authors (with primary reference to certain categories) and exceptions to those rights.

In a nutshell, the DSM Directive was envisaged to apply rights and obligations connected to copyright also online. Its mission is made explicit since the very beginning, as recitals 1 and 2 specify that more common rules on copyright in the European sphere are functional to the existence of a system ensuring that competition in the internal market is not distorted and are expected to stimulate "innovation, creativity, investment and production of new content, also in the digital environment, in order to avoid the fragmentation of the internal market". The amendments produced by the DSM Directive are also aimed to foster the creation and free movement of

\footnotetext{
${ }^{16}$ Also academics all around Europe took a stand against the Commission's proposal. See, for example, Open Letter to Members of the European Parliament and the Council of the European Union, 24 February 2017, at https://www.create.ac.uk/wp-content/uploads/2017/02/OpenLetter_EU_Copyright_Refor m_24_02_2017.pdf (accessed 20 December 2019).

${ }^{17}$ https://www.europarl.europa.eu/news/en/press-room/20180628IPR06809/parliament-to-review-copyr ight-rules-in-september.

18 The report drafted by the first rapporteur, Therese Comodini Cachia, can be found here: http://www. europarl.europa.eu/doceo/document/JURI-PR-601094_EN.pdf?redirect. The one prepared by the second rapporteur, Axel Voss, is available here: http://www.europarl.europa.eu/doceo/document/A-8-20180245_EN.pdf.

19 https://www.europarl.europa.eu/news/en/press-room/20190321IPR32110/european-parliament-appro ves-new-copyright-rules-for-the-internet.

${ }^{20}$ Directive (EU) 2019/790 of the European Parliament and of the Council of 17 April 2019 on copyright and related rights in the Digital Single Market and amending Directives 96/9/EC and 2001/29/EC, OJEU L 130/92. For more comments on Directive (EU) 2019/790 see, inter alia, Quintais 2019, Zancan 2019.
} 
cultural products, thereby strengthening pluralism and European cultural industries against the bargaining power of leading platforms. For brevity, with the DSM Directive it is proposed to secure the proliferation and remuneration of "small players" in the face of Google, Facebook, Youtube and the like. For those reasons, the it paves the way for licencing schemes.

Directive (EU) 2019/790 was designed to reduce Member States' leeway way more than the Infosoc Directive did. The scale, effects and cross-border dimension of the objectives pursued by the reform granted the EU legislator the opportunity to easily demonstrate that the principles of subsidiarity and proportionality could be respected even if the new legal framework would compress the powers of the Member States vis à vis the European Union.

The instrument chosen by the EU legislator is a directive, which is the typical legislative act used in the field of copyright. However, the same is not always true for other forms of protections falling within the category "intellectual property" or with regard to the legislative arsenal built up over last years to develop and fuel the DSM; indeed, the EU preferred to govern some sensitive sectors mainly or exclusively by means of acts whose application is direct and general (e.g. for data protection, ${ }^{21}$ geo-blocking, ${ }^{22}$ portability, ${ }^{23}$ online intermediation services ${ }^{24}$ ).

Like the Infosoc Directive, the DSM Directive has more than one legal basis. The "centre of gravity" is always Art. 114 TFEU (previously, Art. 95 of the Treaty of the Economic Community-EEC) which allows the European Parliament and the Council to adopt measures for the approximation of national laws, regulations or administrative acts in order to ensure establishment and functioning of the internal market.

Contrary to the Infosoc Directive, the DSM Directive is a long piece of legislation; it contains 86 recitals and 32 articles. It is obvious that the European Parliament and the Council (as well as the Commission) strived to adjust to claims coming from many quarters, including the main findings of the Court of Justice.

The 2019 Directive is composed of five titles: general provisions, measures to adapt exceptions and limitations to the digital and cross-border environment, measures to improve licensing practices and ensure wider access to content, measures to achieve a well-functioning marketplace for copyright, final provisions. Next paragraphs will investigate the provisions that are supposed to raise the main concerns.

\footnotetext{
${ }^{21}$ Regulation (EU) 2016/679 of the European Parliament and of the Council of 27 April 2016 on the protection of natural persons with regard to the processing of personal data and on the free movement of such data, and repealing Directive 95/46/EC, OJEU L 119/1.

${ }^{22}$ Regulation (EU) 2018/302 of the European Parliament and of the Council of 28 February 2018 on addressing unjustified geo-blocking and other forms of discrimination based on customers' nationality, place of residence or place of establishment within the internal market and amending Regulations (EC) No 2006/2004 and (EU) 2017/2394 and Directive 2009/22/EC, OJEU LI 60/1.

${ }^{23}$ Regulation (EU) 2017/1128 of the European Parliament and of the Council of 14 June 2017 on crossborder portability of online content services in the internal market, OJEU L 168/1.

${ }^{24}$ Regulation (EU) 2019/1150 of the European Parliament and of the Council of 20 June 2019 on promoting fairness and transparency for business users of online intermediation services, OJEU L 186/57.
} 


\section{Main controversial provisions}

\subsection{Measures to adapt exceptions and limitations to the digital and cross-border environment}

At the outset, it is worth recalling that the DSM Directive does not impact on the three exclusive rights enshrined in the Infosoc Directive. The first is the right to authorise or prohibit direct or indirect, temporary or permanent reproduction by any means and in any form, in whole or in part for the subjects indicated in Art. 2 of Directive 2001/29/EC. ${ }^{25}$ The second right, set up un Art. 3, is the right of the beneficiaries indicated in Art. 2 to authorise or prohibit any communication to the public of their "works" (understood in a broad sense), by wire or wireless means, including the making available to the public of their works in such a way that members of the public may access them from a place and at a time individually chosen by them. The third right is to authorise or prohibit any form of distribution to the public, by sale or otherwise, of the original work or of copies thereof (Art. 4).

On the contrary, Directive (EU) 2019/790 deeply changes the system of exceptions and limitations established by the Infosoc Directive. ${ }^{26}$ The most significant amendments brought by the last reform are two.

First, while exceptions and limitations provided for by Art. 5 of the Infosoc Directive are almost all optional, ${ }^{27}$ new derogations are mandatory. Previously, Member States were not free to affect the exclusive rights of reproduction, communication to the public and distribution by allowing exceptions and limitations other than the ones listed in the 2001 Directive; they could still decide to endorse those exceptions and limitations in their legal orders and, in this case, they had a certain room for manoeuvre to shape said derogations. Only in some instances, Member States had to associate exceptions and limitations to fair compensation.

Exceptions and limitations of the DSM Directive are "pre-packaged" and Member States cannot refrain from transposing them into national law; however, these obligations ultimately target individuals, who will have to stick to new national provisions on copyright adopted, in turn, by Member States to comply with the 2019 Directive.

Most of the new exceptions and limitations do not fully coincide with those contained in the Infosoc Directive. For brevity, the grounds of the 2001 Directive

\footnotetext{
25 Art. 2 of the Infosoc Directive sets forth rights for: authors, on their works; performers, on fixations of their performances; phonogram producers, on their phonograms; producers of the first fixations of films, in respect of the original and copies of their films; broadcasting organisations, on fixations of their broadcasts, whether those broadcasts are transmitted by wire or over the air, including by cable or satellite.

26 The difference between the concepts "exceptions" and "limitations" is not of particular relevance; in the framework of the Infosoc and Copyright Directives, both concepts have the same meaning.

27 The only mandatory exception/limitation under the Infosoc Directive is the one contained in Art. 5(1), concerning transient or incidental copies aimed at facilitating the activities of internet service providers or certain lawful uses. The exceptions and limitations provided for in Art. 5(2-3) are not mandatory. Other exceptions and limitations, either optional or mandatory, are enshrined elsewhere EU copyright acquis.
} 
keep surviving but from the entry into force of the DSM Directive will be sided (or replaced?) by compulsory derogations at national level. The exceptions and derogations added by the DSM Directive can be resumed as follows.

Art. 3 is about acts of text and data mining (TDM) ${ }^{28}$ for the purposes of scientific research carried out by research organisations and cultural heritage institutions. That applies if the activities concerned refer to works/subject matter to which those organisations and institutions have lawful access; however, TDM exceptions and derogations are subject to other conditions.

Art. 4 covers reproductions and extractions of works and subject matter which have been lawfully accessed for the purposes of TDM. This derogation can be applied provided that the use of the abovementioned materials has not been expressly reserved by right holders "in an appropriate manner"; the provision makes the example of machine-readable means in the case of content made publicly available online. In any event, right holders' reservation shall not affect Art. 3. The fact remains that this is the only exception/limitation which can be overridden by contract. $^{29}$

Art. 5 allows the digital use of works and other subject matter for the sole purpose of illustration for teaching. Keeping in mind the findings of the 2018 Renckhoff judgement, ${ }^{30}$ this derogation appears to be particularly topical and echoes the content of Art. 5(3)(a) of the Infosoc Directive. Despite the adjustment made by the EU legislator, the protection afforded by Art. 5 of Directive (EU) 2019/790 is not absolute. This derogation can be invoked to the extent justified by the non-commercial purpose to be achieved. Moreover, it applies if the use of copyrighted materials takes place under the responsibility of an educational establishment and if the source and the author's name are duly indicted (unless this turns out to be impossible). Instead, fair compensation for right holders is a surplus that Member States are free to endorse in national regulations. Exceptions and limitations under Art. 5 are peculiar, in the sense that they are "quasi-mandatory". Member States could not abide by them (in whole or in part) if they take necessary measures to ensure that educational establishments are placed in the proper conditions to get suitable licences on the market.

Art. 6. concerns acts of reproduction of some cultural heritage institutions' works. This derogation operates only for preservation purposes.

\footnotetext{
28 Text and data mining means "any automated analytical technique aimed at analysing text and data in digital form in order to generate information which includes but is not limited to patterns, trends and correlations" (Art. 2(2)). However, those limitations do not apply in the fields of software and databases. Fore more information see Bottis et al. 2019, Geiger et al. 2018.

29 Art. 7(1) of Directive (EU) 2019/790. Prior to the adoption of the Copyright Directive, there were no significant restriction to contractual disposition of the existing exceptions and limitations (especially those contained in the Infosoc Directive).

${ }^{30}$ See supra (n. 13). The case was about the posting of a student's assignment containing a copyright protected work downloaded from a website. See also Opinion of the European Copyright Society Concerning the Scope of the Economic Rights in Light of Case C-161/17, Land Nordrhein Westfalen v. Dirk Renckhoff ('Córdoba case') https://europeancopyrightsocietydotorg.files.wordpress.com/2018/10/ecsopinion-renckhoff-cordoba-final.pdf accessed 20 December 2019. In addition, see Saw 2018 and Synodinou 2018.
} 
All those exceptions and limitations seem to have in common quite narrow scopes and the feeling is that their added value in terms of civil society's rights and legitimate interests will fall short. Additionally, basing on Art. 7(2) of the DSM Directive all of them can be put in place only if the proportionality test specifically designed in Art. 5(5) of the Infosoc Directive is complied with, meaning that triggering the exception/limitation does not conflict with a normal exploitation of the work or other subject-matter and it does not cause unreasonable prejudice to the right holder's legitimate interests.

Not less important is that Art. 7(2) tends to limit the effectiveness of exceptions and limitations with respect to the need of avoiding circumvention of efficient technological protection measures designed to protect the exclusivity of core authors' rights. $^{31}$

\subsection{Provisions on press publishers' rights}

One of the most debated aspects of the Directive was (and still remains) the so called "link tax" included in Art. 15 of the Directive. ${ }^{32}$

This article extends the rights of reproduction and of communication to the public-Arts. 2 and 3(2) of the Infosoc Directive-to publishers of press publications established in a Member State. If another subject wants to make use of the protected item, press publishers will be entitled to receive a fair compensation under national law.

The reason why such amendment to the pre-existing EU legal regime on copyright was intensively negotiated and finally introduced is that in the digital ecosystem press publishers have difficulty in licensing their rights to new generation information society providers, like online news aggregators and media monitoring services. So, with Art. 15 of the DSM Directive, the EU legislator tries to make sure that Member States secure press publishers' investment in a new business environment. In addition, protecting the sustainability and the proliferation of the publishing industry through the link tax is ultimately supposed to be a further guarantee for the dissemination of reliable information.

Beneficiaries of the right shaped in Art. 15 are operators dealing with press publication. Art. 2(4) of the Directive defines "press publication" as "a collection composed mainly of literary works of a journalistic nature, but which can also include other works or other subject matter, and which: (a) constitutes an individual item within a periodical or regularly updated publication under a single title, such as a newspaper or a general or special interest magazine; (b) has the purpose of providing the general public with information related to news or other topics; and (c) is published in any media under the initiative, editorial responsibility and control of a service provider". While the notion of "press publication" is quite broad, there are

\footnotetext{
31 Indeed, Art. 7(2) of the Copyright Directive subjects the exceptions and limitations provided for in Arts. 3-6 to Art. 6(4) of the Infosoc Directive, which regulates the application of technological protection measures vis à vis the exceptions and limitations of that piece of legislation.

32 See also Papadopoulou et al. 2020.
} 
some exclusions as well. In particular, the right at stake does not cover periodicals published for scientific or academic purposes, nor does it apply to private or noncommercial uses of press publications by individual users, ${ }^{33}$ acts of hyperlinking, ${ }^{34}$ and in respect of the use of individual words or very short extracts of a press publication. ${ }^{35}$ Generally speaking, the final version of the act relieves the rigid architecture of the Commission's proposal.

Press publishers' rights are for sure neither timeless nor absolute. They last two years from 1 January of the year following the date of the publication. ${ }^{36}$ Art. 15 of Directive (EU) 2019/790 also requires the application of some provisions of the Infosoc Directive; for example, the voluntary exceptions and limitations listed in Art. 5 and the provisions laid down to ensure the protection of technological measures and rights-management information (Arts. 6 and 7). Likewise, the DSM Directive is without prejudice of the directives on certain permitted uses of both orphan works ${ }^{37}$ and of works/other subject matter protected by copyright and related rights for the benefit of persons who are blind, visually impaired or otherwise print-disabled. ${ }^{38}$

Furthermore, Art. 15 rights shall co-exist with the rights that EU law confers to authors and other right holders with reference to the works and other subject matter incorporated in a press publication and not covered by an exclusive license. A corollary of this limitation is that the materials in question have to be treated independently from the press publication where they are included. Above all, authors of works incorporated in a press publication shall receive "an appropriate share of the revenues that press publishers receive for the use of their press publications by information society service providers".

Finally, Art. 16 of the DSM Directive allows Member States to consider the transfer or the license of a right by an author to a publisher as a sufficient legal basis to entitled the latter to a share of the compensation for the use of the work made under an exception or limitation to the transferred or licensed right. ${ }^{39}$

\footnotetext{
33 For example, uploading materials on online encyclopedias which do not have commercial purposes or on platforms for the sharing of open source software and on cloud are activities not targeted by the Copyright Directive.

${ }^{34}$ Conversely to links, short snippets (the words describing an article) are not mentioned in Art. 15 of Directive (EU) 2019/790.

35 Memes, parodies, quotations and pastiches do not amount to breaches of the new legal framework on copyright at EU level.

36 Those rights do not apply to press publications first published before 6 June 2019. See Art. 15(4) of Directive (EU) 2019/790.

37 Directive 2012/28/EC of the European Parliament and of the Council of 25 October 2012 on certain permitted uses of orphan works, OJEU L 299/5.

38 Directive 2012/28/EC of the European Parliament and of the Council of 13 September 2017 on certain permitted uses of certain works and other subject matter protected by copyright and related rights for the benefit of persons who are blind, visually impaired or otherwise print-disabled and amending Directive 2001/29/EC on the harmonisation of certain aspects of copyright and related rights in the information society, OJEU L 242/6.

39 According to Recital (60), Art. 16 does not merely refer to publishers of press publications, but also to publishers of books or scientific publications and music publications. Those subjects generally operate on the basis of the transfer of authors' rights by means of contractual agreements or statutory provisions. In some Member States, for uses under certain exceptions or limitations, the investment made by pub-
} 
The introduction of press publishers' rights was highly criticized by many commentators. ${ }^{40}$ It is argued that the press publishers are already well protected and that the new rights, which are territorial, would harm market freedoms, freedom of expression and freedom of art. That would also affect innovation in the EU. Most notably, although the scope of application of press publishers' rights was slightly reduced in the final text of the Directive, it seems that new rights can extend to the vast majority of the forms of use. That happens even if, according to some experts, there was no empirical evidence to justify such new regime. ${ }^{41}$

Next to this, many points of Art. 15 are rather vague and need to be further clarified; it is expected that the ECJ will be frequently asked to interpret this provision in order to better align national regulations-already existing or soon to be adoptedto the Directive. For instance, more comprehensive criteria shall be put forward to assess in advance the meaning of certain expressions: for example, "non-commercial uses" of press publications, ${ }^{42}$ "very short extracts of a press publication", "appropriate share" of the revenues received by press publishers. At the same time, it is hard not to see that Member States remain quite much free to decide how to implement relevant rights recognized and guaranteed by Art. 15 and to decide the ways through which remuneration shall be ensured to right holders.

\subsection{New service providers' duties}

Another controversial provision of the DSM Directive is the "upload filter" guarantee enshrined in Art. 17. ${ }^{43}$ As noted above, the Infosoc Directive does not adequately shield right holders from illicit online activities on protected materials. This is all the more true when protected materials are shared by broad-dimension market players. Therefore, Art. 17 was shaped in an attempt to safeguard the revenue of right holders when they produce creative contents to be circulated online. On the other hand, Art. 17 seeks to narrow down big players' power to take advantage of the creative outcomes of right holders.

To do that, the provision at hand reverses the previous liability scheme at the expense of online service providers. The "upload filter" guarantee is a significant manifestation of a trend underpinning the DSM strategies ${ }^{44}$ and is turning to be a

Footnote 39 (continued)

lishers indicated in Recital (60) is somehow protected by the provision of a compensation to be shared with the authors.

${ }^{40}$ Institute of International Law - University of Amsterdam, Academics Against Press Publishers' Right https://www.ivir.nl/academics-against-press-publishers-right/ accessed 20 December 2019. See also.

41 Colangelo and Torti 2018.

42 As an example, what if a user reproduces the text of a material falling under the scope of application of the Directive for non-profit-making activities but he/she avails of a platform which generates revenues by means of advertising?.

43 Further details are provided in Spindler 2020 and Grisse 2019.

44 As for new scenarios for platforms' liability in the DSM see Montagnani and Yordanova Trapova 2019. 
breakthrough in the domains of copyright and e-commerce, since its very essence is to make those subjects directly liable for their users' uploads.

Art. 17 of Directive (EU) 2019/790 addresses online content-sharing service providers ("OCSSPs"). An OCSSP is a "provider of an information society service of which the main or one of the main purposes is to store and give the public access to a large amount of copyright-protected works or other protected subject matter uploaded by its users, which it organises and promotes for profit-making purposes". It is clear from the outset that Art. 17 intends to "capture" a huge variety of service providers; however, it primarily targets worldwide-spectrum online platforms.

Under the new legal conditions established by Art. 17(1-2), OCSSPs communicate or make public contents the public when they give the public access to copyrighted works uploaded by their users. OCSSPs will then be allowed to communicate or make available to the public works or other subject matter only upon authorisation from the right holders. Authorizations shall also cover acts carried out by users of the services falling within the scope of Art. 3 of Directive 2001/29/EC (see supra) when they are not acting on a commercial basis or where their activity does not generate significant revenues. Art. 17(2) places greater emphasis on licensing agreements but authorisations might as well take a different form; in any case, Member States shall build up legal avenues to facilitate the conclusion of agreements between the parties, in particular licensing agreements.

Here the problem is that if the authorization is not released, the OCSSPs shall be liable for acts of communicating and making available to the public copyright-protected works and other subject matter. It goes without saying that this requirement constitutes an almost insurmountable obstacle for any OCSSP, being impossible to receive countless numbers of authorisations. Now, it is true that, compared to the Commission's proposal, in the Directive the obligations on OCSSPs were slightly mitigated. Similarly, Art. 17(8) excludes that OCSSPs shall be compelled to respect general monitoring obligations under the new Directive; indeed, this prohibition appears to endorse the ECJ's main findings on the matter. ${ }^{45}$ Nevertheless, due to empirical and legal issues affecting new obligations, the DSM Directive falls short from safeguarding OCSSPs' prerogatives from this point of view, ${ }^{46}$ to the point that Art. 17(8) comes down to a sort of "political statement". 47 The new regime will possibly be based on complex algorithms and turn OCSSPs in (inefficient) "web police officers". Given the lack of legislative guiding criteria on how authorizations should be released, that in the end will result in pushing some OCSSPs (those who can afford that) to resort to costly solutions; paradoxically, filters or similar mechanisms. The short-circuit is even more clear if the attention is moved towards Arts. 14 and 15 of the E-commerce Directive, which rules out this type of burdens. ${ }^{48}$

\footnotetext{
${ }_{45}$ See in particular, the SABAM and Scarlet Extended judgments (n. 13).

46 For further references on the side effects of increasing platforms' liability in the DSM, see Colangelo and Maggiolino 2018, Frosio 2017.

47 Pereira 2019.

48 Art. 14(1) of Directive 2000/31/EC runs as follows: "(w)here an information society service is provided that consists of the storage of information provided by a recipient of the service, Member States shall ensure that the service provider is not liable for the information stored at the request of a recipient of the service, on condition that: (a) the provider does not have actual knowledge of illegal activity
} 
At the same time, technical issues pinpointed or simply envisaged so far are meant to be such to increase the risk of prior restraint or the elimination of lawful contents, thereby infringing upon freedom of expression. As rightly pointed out, "over-blocking and excessive filtering could too easily lead to censorship". 49

Maybe this is the real reason why in the remaining paragraphs of Art. 17 the drafters of the Directive included provisions aimed to curb the likely disruptive effects of the "upload filter" guarantee.

To start with, Art. 17(4) stipulates that OCSSPs can avoid liability for unauthorized conducts if they demonstrate that they have fulfilled three cumulative preventive obligations. First, they have made best efforts to obtain an authorization from the right holders. Second, they have made best efforts to ensure, in accordance with high industry standards of professional diligence, the unavailability of the works or other subject matter for which the right holders have provided relevant and necessary information. In a few words, OCSSPs shall put in place technological devices to recognize and detect video, music, photos, codes and other materials protected by copyright. Third, after receiving a sufficiently substantiated notice from the right holders, they have acted expeditiously to disable access to, or to remove from their websites, the notified works or other subject matter, and made best efforts to prevent their future uploads in accordance with the previous point. As one can see, the fruit of the work of the trilogue is the emergence of an accountability principle that, to some extent, follows the inputs coming from the GDPR.

Not all OCSSPs are entirely subject to Art. 17(4) of Directive (EU) 2019/790. By virtue of Art. 17(6) Member States shall provide that OCSSPs which have been available to the public in the EU for less than 3 years and which have an annual turnover below EUR 10 million, are limited to compliance only with the first preventive obligation of Art. 17(4). They also have to act expeditiously, upon receiving a sufficiently substantiated notice, to disable access to the notified works or other subject matter or to remove those works or other subject matter from their websites. They will be required to demonstrate that they have made best efforts to prevent further uploads of the notified works and other subject matter for which the right holders have provided relevant and necessary information only if their average number of monthly unique visitors exceeds 5 million, calculated on the basis of the previous calendar year.

However, failure to meet one or more of the requirements enumerated in Art. 17(4) does not entail the automatic liability of an OCSSP. The fifth paragraph pf Art. 17 prescribes that the assessment of the OCSSPs' overall conduct must be carried out by taking account of the main elements of the case concerned ${ }^{50}$ and in the

\footnotetext{
Footnote 48 (continued)

or information and, as regards claims for damages, is not aware of facts or circumstances from which the illegal activity or information is apparent; or (b) the provider, upon obtaining such knowledge or awareness, acts expeditiously to remove or to disable access to the information". Art. 15 excludes general monitoring obligations.

49 Mostert 2019, p. 742.

50 Art. 17(5) of the Copyright Directive provides for a non-exhaustive list of factors that must be considered when carrying out the assessment in order to comply with Art. 17(4). Art. 17(5) mentions "a) the type, the audience and the size of the service and the type of works or other subject matter uploaded by
} 
light of the proportionality principle. It will be up to national judiciaries and, where necessary, to the ECJ to get this straighter in the near future.

Finally, Art. 17(7) establishes that OCSSP's preventive obligations should not prevent that content uploaded by users is available if that conduct does not infringe copyright. Art. 17(7) also introduces a special regime for some exceptions and limitations claimed by given users when they upload and make available content generated by other users on OCSSPs. The former shall be allowed by Member States to rely on derogations like quotation, criticism, review, caricature, parody or pastiche. Those grounds are already present in the Infosoc Directive and are to be recognized an independent meaning under EU law. ${ }^{51}$ However, exceptions and limitations contained in Art. 17(7) are-once again-mandatory, ${ }^{52}$ unlike those listed in Art. 5 of the Infosoc Directive. As observed by some renown scholars, if conflicts between Art. 17(7) of the DSM Directive and Art. 5 of the InfoSoc Directive occur, the former creates an obligation under EU law to implement national exceptions and limitations "that offer the minimum user privileges to which Article 17(7) refers". 53 Over and above that, this provision is of utmost importance because, in line with what suggested by Recital (70), it will have a key part in the fair balance to strike when divergent interests give rise clashes between fundamental right to property, including intellectual property, ${ }^{54}$ and freedom of expression and/or freedom of the arts. ${ }^{55}$ In bears noting that in so doing the EU legislator has embarked, at least in part, in an activity that until present has traditionally been carried out by the ECJ in copyright-related cases.

As for disputes, the DSM Directive provides for the establishment of dedicated systems. Art. 17(9) demands the introduction of national provisions to oblige OCSPs to put in place effective and expeditious complaint and redress mechanisms that users can trigger to challenge the disabling of access to, or the removal of, works or other subject matter uploaded by them. For the avoidance of doubt, Art. 17(9) does not prevent users from bringing proceedings before national judiciaries, as it provides for a mandatory mechanism to be in an optional manner.

\footnotetext{
Footnote 50 (continued)

the users of the service; and (b) the availability of suitable and effective means and their cost for service providers".

51 See for example the Dechmyn judgment (ECJ, n. 14). See also Griffiths et al. 2013.

52 They are mandatory not only with regard to the acts covered by the specific right of communication to the public but also for all acts of uploading or making available by users through OCSPs.

53 Quintais et al. 2019, p. 2.

54 Art. 17(2) of the Charter of Fundamental Rights.

55 Arts. 11 and 13 of the Charter of Fundamental Rights.
} 


\section{Conclusions}

With the DSM Directive, the European Union has fleshed out ambitious goals and has initiated a brand new era. For sure, legal and practical consequences cannot be properly evaluated at this stage, as it is necessary to wait for the implementation of the Directive by all Member States.

However, the analysis developed in the present article makes it possible to envisage likely scenarios and to spot some weak points of the copyright reform brought about by the EU.

Unfortunately, since the very beginning of the procedure leading to the final version of Directive (EU) 2019/790 it appeared indisputable that the new set of rules on copyright would have failed to achieve a fair balance between competing interests and would have been driven mostly by the activity of influential lobbies rather than sectoral experts. Then in all likelihood, controversial aspects will override positive effects. In particular, two major concerns can be pointed out right now.

(A) Member States keep retaining broad powers, primarily because the Directive rests on too many unclear concepts. ${ }^{56}$ Just a few examples: how to determine "the main or one of the main purposes" of an OCSSP? What is "a large amount of copyright protected works"? How to find out if the OCSSP has made "best efforts"? And what about the definitions of many other notions or activities that are not sufficiently clarified by the Directive? The truth is that national regulations brought into being to give effect to the Directive will vary from one Member State to another. So, it is possible that one of the main purposes of the DSM Directive - namely tearing down domestic barriers hindering transnational digital activities by harmonizing certain aspects of EU copyright law-will remain a dead letter and it looks like the legal certainty desired by the EU will keep being a pipe dream. It is believed, if anything, that the ECJ will be filed with a number of preliminary rulings for interpretation and that it will continue to exercise a "quasi-legislative" function.

(B) The DSM Directive will probably end up restricting the category of "actual beneficiaries" of EU copyright law. The narrow scope of the exceptions, the role played by technical protection measures and the existence of technical difficulties emerging from the obligations established in Arts. 15 and 17 cannot but hamper the interests of many users and a lot of small/medium service providers. The former could face plenty of obstacles in terms of their access to and use of works or other subject matter; the latter-especially small and medium providers-will find it hard (or at times impossible) to bear the weight of the burdens incumbent upon them by virtue of the "link tax" and the "upload filter". Due to such lack of simplification, the position of tech giants will emerge even strengthened. This opinion is also supported by an example stemming from national practice. France has already implement the DSM Directive; however, the new French regulation (and, as a consequence, the Directive itself) is proving unable

56 See also Falce 2019 and Morelli 2019. 
to counter Google's bargaining power towards its counterparts. Indeed, Google has communicated that it will show articles, pictures and videos in search results only if media firms refrain from asking for compensation. ${ }^{57}$ Therefore, also the long proclaimed intention to foster information-in terms of quality, free flow and pluralism - together with granting greater access to items circulating online, is being jeopardized right from the beginning. Again, there will still be much work to do for the ECJ; and presumably, many national disputes will turn into fundamental rights clashes before the Court, no less.

One last remark. It should not be overlooked that Directive (EU) 2019/790 only deals with "traditional" items uploaded through the internet; instead, contents which are not produced by creative industries do not fall within the scope of application of the Directive. Notwithstanding, works and subject matter created by the wider public and shared via the internet are expected to be at the forefront of a growing number of disputes for reasons of copyright. That ultimately shows that even after last reform EU copyright law does not cease to be quite fragmented and inconsistent, but continues to remain incomplete.

Funding Open access funding provided by Alma Mater Studiorum - Universit $\tilde{A}$ di Bologna within the CRUI-CARE Agreement.

Open Access This article is licensed under a Creative Commons Attribution 4.0 International License, which permits use, sharing, adaptation, distribution and reproduction in any medium or format, as long as you give appropriate credit to the original author(s) and the source, provide a link to the Creative Commons licence, and indicate if changes were made. The images or other third party material in this article are included in the article's Creative Commons licence, unless indicated otherwise in a credit line to the material. If material is not included in the article's Creative Commons licence and your intended use is not permitted by statutory regulation or exceeds the permitted use, you will need to obtain permission directly from the copyright holder. To view a copy of this licence, visit http://creativecommons.org/ licenses/by/4.0/.

\section{References}

Bottis M et al (2019) Text and data mining in Directive 2019/790/EU enhancing web-harvesting and web-archiving in libraries and archives. Open J Philos 9:369-395

Caso R, Giovannella F (eds) (2015) Balancing copyright law in the digital age. Springer, Cham

Colangelo G, Maggiolino M (2018) ISPs' copyright liability in the EU Digital Single Market strategy. Int J Law Inf Technol 26:142-159

Colangelo G, Torti V (2018) Copyright, online news publishing and aggregators: a law and economics analysis of the EU Reform. Int J Law Inf Technol 27:75-90

Falce V (2019) Direttiva Copyright 2019: fair use ed eccezioni al copyright tra esigenze di "apertura" e necessità di indirizzo. Filodiritto.it https://www.filodiritto.com/direttiva-copyright-2019-fair-useed-eccezioni-al-copyright-tra-esigenze-di-apertura-e-necessita-di-indirizzo. Accessed 20 Dec 2019

Frosio GF (2017) Reforming intermediary liability in the platform economy: a European Digital Single Market Strategy. Northwest Univ Law Rev 112:19-46

\footnotetext{
57 See, for example, https://www.european-views.com/2019/10/french-media-to-sue-google-for-refusingto-pay-under-eus-new-copyright-law/ accessed 20 December 2019.
} 
Geiger C et al (2018) The exception for Text and Data Mining (TDM) in the Proposed Directive on Copyright in the Digital Single Market-legal aspects. http://dx.doi.org/10.2139/ssrn.3160586. Accessed 20 Dec 2019

Gervais DJ (2017) (Re)structuring copyright: a comprehensive path to international copyright reform. Edward Elgar, Chentelham

Griffiths et al (2013) Limitations and exceptions as key elements of the legal framework for copyright in the European Union-opinion on the Judgment of the CJEU in Case C-201/13 Deckmyn. https:// papers.ssrn.com/sol3/papers.cfm?abstract_id=2564772. Accessed 20 Dec 2019

Griffiths J, McDonagh LT (2013) Fundamental Rights and European IP Law: the Case of Art 17(2) of the EU Charter. In: Geiger C (ed) Constructing European intellectual property: achievements and new perspectives. Edward Elgar, Chentelham, pp 75-92

Grisse K (2019) After the storm-examining the final version of Article 17 of the new Directive (EU) 2019/790. J Intellect Property Law Pract 14:887-899

Husovec M (2016) Intellectual property rights and integration by conflict: the past, present and future. Camb Yearbook Eur Legal Stud 18:239-269

Montagnani ML, Yordanova Trapova A (2019) Safe harbours in deep waters: a new emerging liability regime for Internet intermediaries in the Digital Single Market. Int J Law Inf Technol 26:294-310

Morelli L (2019) EU Directive on copyright in the Digital Single Market: new liability for online contentsharing service providers. https:/www.mwe.com/insights/eu-directive-on-copyright-in-the-digit al-single-market-new-liability-for-online-content-sharing-service-providers/. Accessed 20 Dec 2019

Mostert F (2019) To regulate or not to regulate online speech, that is the question. J Intellect Property Law Pract 14:741-742

Papadopoulou M-P et al (2020) Copyright and the Press Publishers right on the Internet: evolutions and perspectives. In: Synodinou $\mathrm{T}$ et al (eds) EU Internet Law in the digital era: regulation and enforcement. Springer, Cham, pp 99-136

Pereira M (2019) The new Copyright Directive: online content-sharing service providers lose eCommerce Directive immunity and are forced to monitor content uploaded by users (Article 17). Kluwer Copyright Blog. http://copyrightblog.kluweriplaw.com/2019/09/26/the-new-copyright-directiveonline-content-sharing-service-providers-lose-ecommerce-directive-immunity-and-are-forced-tomonitor-content-uploaded-by-users-article-17/. Accessed 20 Dec 2019

Quintais J (2019) The new copyright in the Digital Single Market Directive: a critical look. https://ssrn. com/abstract=3424770 or http://dx.doi.org/10.2139/ssrn.3424770. Accessed 20 Dec 2019

Quintais J et al (2019) Safeguarding user freedoms in implementing Article 17 of the copyright in the Digital Single Market Directive: recommendations from European Academics. https://papers.ssrn. com/sol3/papers.cfm?abstract_id=3484968. Accessed 20 Dec 2019

Ramalho A (2016) The competence of the European Union in copyright lawmaking. Springer, Cham

Ricolfi M (2013) Consume and share: making copyright fit for the Digital Agenda. In: Geiger C (ed) Constructing European intellectual property: achievements and new perspectives. Edward Elgar, Chentelham, pp 314-326

Rosati E (2019) Copyright and the Court of Justice of the European Union. Oxford University Press, Oxford

Rosenmeier M (2019) EU Copyright Law: subsistence, exploitation and protection of rights. Kluwer Law International, Alphen aan den Rijn

Saw CL (2018) Implications of reposting copyright material online and Svensson distinguished in CJEU Judgment: Land Nordrhein-Westfalen v Dirk Renckhoff. Singap Acad Law J 30:1126-1132

Spindler G (2020) Copyright law and internet intermediaries liability. In: Synodinou T et al (eds) EU Internet Law in the digital era: regulation and enforcement. Springer, Cham, pp 3-25

Stamatoudi I, Torremans P (2014) EU Copyright Law. A commentary. Edward Elgar, Cheltenham

Synodinou T (2018) The Renckhoff judgment: the CJEU swivels the faces of the Copyright Rubik's Cube (Part II). Kluwer Copyright Blog. http://copyrightblog.kluweriplaw.com/2018/10/02/renckhoffjudgment-cjeu-swivels-faces-copyright-rubiks-cube-part-ii/. Accessed 20 Dec 2019

Zancan M (2019) La nuova direttiva sul diritto d'autore e sui diritti connessi nel mercato unico digitale. MediaLaws 2:338-345 